\title{
Correction to: Comparison of laparoscopic transabdominal preperitoneal hernioplasty and laparoscopic iliopubic tract repair for Nyhus type II hernia in women
}

\author{
Sung Ryul Lee ${ }^{1}$ [D $\cdot$ Jin Young Park ${ }^{1}$
}

Published online: 9 December 2021

(c) The Author(s), under exclusive licence to Springer Science+Business Media, LLC, part of Springer Nature 2021

\section{Correction to: Surgical Endoscopy (2021) 35:7260-7266 https://doi.org/10.1007/s00464-021-08739-w}

This article was updated with a corrected version of Fig. 2 .

Publisher's Note Springer Nature remains neutral with regard to jurisdictional claims in published maps and institutional affiliations.

The original article can be found online at https://doi.org/10.1007/ s00464-021-08739-w.

Sung Ryul Lee

kingsoss@naver.com

Jin Young Park

jenny5260@ naver.com

1 Department of Surgery, Damsoyu Hospital, 234 Hakdong-ro, Gangnam-gu, Seoul, Republic of Korea 